\title{
Calamus arborescens (Arecaceae): an addition to the flora of India from West Bengal
}

\author{
Mondal S. ${ }^{1}$, Basu S.K. ${ }^{2}$ \& M. Chowdhury ${ }^{1 *}$ \\ ${ }^{1}$ Taxonomy of Angiosperms and Biosystematics Lab., Dept. of Botany, University of North Bengal, \\ Raja Rammohunpur, Darjeeling, West Bengal - 734 013, India \\ ${ }^{2}$ The Agri Horticultural Society of India, Kolkata, West Bengal - 700 027, India \\ ^E-mail: mono_malda@yahoo.co.in
}

\begin{abstract}
Calamus arborescens Griff. (Arecaceae) is reported here as a new record for India, based on collections from the eastern Himalayan region of West Bengal. This species had previously been known to occur from Myanmar and Thailand. A detailed description along with photographs is provided.
\end{abstract}

Keywords: Darjeeling, Himalaya, India, Rattans, West Bengal.

\section{Introduction}

Calamus L., the largest genus in Arecaceae, comprising about 400 species, is distributed in tropical and subtropical Africa, Asia and Australia (Mondal et al., 2019, 2020; Henderson, 2020). Hooker (1894) listed 72 species of Calamus for undivided British India. Presently around 48 species and three varieties of rattans are reported to occur in India, distributed mainly in various parts of the Himalayan region, Western Ghats and Andaman \& Nicobar Islands (Basu, 1992; Noltie, 1994; Mondal \& Chowdhury, 2018; Mondal et al., 2019, 2020).

During field trips in the forest areas of Sittong (alt. approx. 300-350 m), located between the lower range of the Senchal Wildlife Sanctuary and the upper range of the Mahananda Wildlife Sanctuary in Darjeeling district, West Bengal, the authors came across a specimen of Calamus. The specimen

Received: 14.12.2020; Revised \& Accepted: 27.04.2021

Published Online: 30.06.2021 bears large leaves without cirrhus, flagella and knee along with a most distinguished feather silvery or grayish white indumentum on the abaxial side of leaflets. On the basis of taxonomic studies of the relevant literature (Griffith, 1850; Basu, 1979; Alam, 1990; Renuka, 1992, 1995; Mondal, 2020) and on comparison with the type specimen housed at CAL, it was identified as Calamus arborescens Griff.. This species hitherto has no natural distribution in India, but was introduced to the Indian Botanic Garden, Howrah in 1810, collected from Pegu, Myanmar. This species now continues to grow in the gardens of several BSI regional circles like Andaman and Nicobar Regional Centre (Port Blair), Arunachal Pradesh Regional Centre (Itanagar) and is cultivated in some regions of Manipur (Basu, 1992). It is reported here as a new distributional record for the region and a detailed description with photographs is provided for identification.

\section{Taxonomic Treatment}

Calamus arborescens Griff., Cal. J. Nat. Hist. 5: 33. 1845; Becc. in Hook.f., Fl. Brit. Ind. 6: 439. 1892; Becc., Ann. Roy. Bot. Gard. Cal. 11: 70.1908 \& Appendix Pl. 1. 1913; Basu, Rattans in Ind. Monogr. Rev. 72. 1992; Mitra \& Sharma, J. Bamboo Rattan 4: 399. 2005. Lectotype: (designated by Henderson, 2020): INDIA, East Bengal, s.loc., s.d., Griffith 6378 (CAL [CAL0000057110!]). Fig. 1 Non-climbing colony forming rattans. Stems erect, 3-6 $\mathrm{m}$ long, 4-7 cm in diam. near base, annulate. Knee absent. Leaves arching, $3 \mathrm{~m}$ long; rachis 


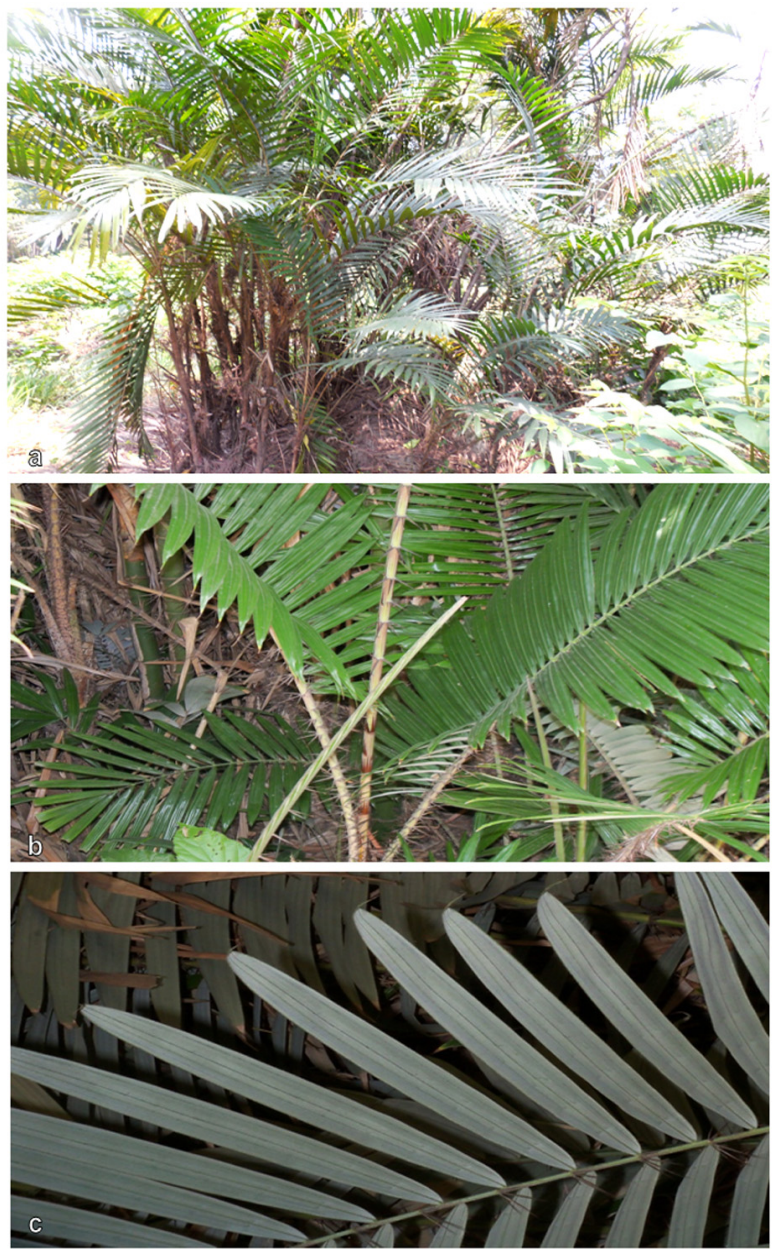

Fig. 1. Calamus arborescens Griff. a. Habit; b. Juvenile stage; c. Abaxial surface of leaflets with grayish white indumentum (photos by S. Mondal).

covered with thick, black, subulate spines, seriate to pectinate, $1.6 \mathrm{~cm}$ long; leaflets lanceolate, equidistant, 45-55 on each side of rachis, 60$84 \mathrm{~cm}$ long, acuminate, thinly bristly at apices, prominently bristly on upper and lower nerves, whitish beneath. Inflorescence pendulous, nonflagelliform, compressed, 1.6-2 m long, strongly armed with black comb-like spines; peduncles smooth, compressed, green; bracts 20-32 cm long, thickly spiny below; male rachillae scorpioid. Male flowers distichous; calyx copular, 3-lobed, leathery; petals acute, valvate, filaments longer than corolla; anthers linear, extended; pistillode angular with 3 abortive carpels. Female flowers not seen. Fruits oblongellipsoid, 2-2.2 $\times 0.5-0.7 \mathrm{~cm}$, brown, prominently beaked with stigmatic projection, scales yellowish.

Flowering \& fruiting: Flowering from November to December and fruiting from April to May.

Habitat: Grows on hilly slopes of sub-tropical forests in the lower hills of eastern Himalaya (300$350 \mathrm{~m}$ alt.) of Darjeeling district, associated with Wallichia caryotoides Roxb. (Arecaceae), Phlogacanthus thyrsiformis (Roxb. ex Hardw.) Mabb. (Acanthaceae), Tetrastigma leucostaphylum (Dennst.) Alston ex Mabb. (Vitaceae), Ficus squamosa Roxb. (Moraceae), Syzygium formosum (Wall.) Mason. (Myrtaceae).

Distribution: India, Myanmar and Thailand.

Specimens examined: INDIA, West Bengal, Darjeeling district, Sittong area, N 26 52'18.33",

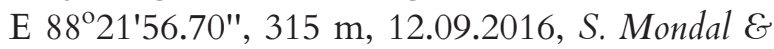
M. Chowdhury 1013; Ibid., 29.09.2020, S. Mondal \& M. Chowdhury 1041 (NBU).

\section{Acknowledgements}

The authors are grateful to the authorities of CNH, ASSAM, NBU, BSIS for facilitating access to specimens and literature and providing expert opinion; and to the forest officials, Department of Forest, Govt. of West Bengal, India for issuing the necessary permit for fieldwork.

\section{Literature Cited}

ALAM M.K. 1990. Rattans of Bangladesh. Bangladesh Forest Research Institute. Chittagong.

BASU S.K. 1979. A census of palms cultivated in the Indian Botanic Garden, Howrah. Principes 22: 127-135.

BASU S.K. 1992. Rattans (Canes) in India: a monographic revision. Rattan Information Centre, Kuala Lumpur.

GRIFFITH W. 1850. Palms of British East India. Charles A. Serrao, Kolkata.

HENDERSON A. 2020. A revision of Calamus (Arecaceae, Calamoideae, Calameae, Calaminae). Phytotaxa 445(1): 001-656. https://doi.org/10.11646/phytotaxa.445.1.1

HOOKER J.D. 1894. Flora of British India. Volume 6. L. Reeve \& Co. Ltd., London. 
MONDAL S. \& M. CHOWDHURY 2018. Rattan diversity in West Bengal, India. Advances in Plant Sciences 31(2): 159-165.

MONDAL S., BASU S.K. \& M. CHOWDHURY 2019. Calamus pseudoerectus (Arecaceae), a new species from the eastern Himalaya, India. Journal of Threatened Taxa 11: 13605-13610. https://doi.org/ 10.11609/jott.4493.11.5.13605-13610

MONDAL S., BASU S.K. \& M. CHOWDHURY 2020. A new species of Calamus (Arecaceae) from Eastern
Himalaya, India. Turczaninowia 23(3): 92-98. http:// turczaninowia.asu.ru/article/view/8561

MONDAL S. 2020. Taxonomy, phenology and ethnobotany of palms in West Bengal. Ph.D. Thesis (unpublished). University of North Bengal.

NOLTIE J.H. 1994. Flora of Bhutan. Royal Botanic Garden Edinburgh.

RENUKA C. 1992. Rattans of the Western Ghats: a taxonomic manual. KFRI, Peechi.

RENUKA C. 1995. A manual of rattans of Andaman and Nicobar Islands. KFRI, Peechi. 